\title{
Patient-tailored modulation of the immune system may revolutionize future lung cancer treatment
}

\author{
Marlies E Heuvers ${ }^{1}$, Joachim G Aerts ${ }^{1,2}$, Robin Cornelissen ${ }^{1}$, Harry Groen ${ }^{3}$, Henk C Hoogsteden ${ }^{1}$ \\ and Joost P Hegmans ${ }^{1^{*}}$
}

\begin{abstract}
Cancer research has devoted most of its energy over the past decades on unraveling the control mechanisms within tumor cells that govern its behavior. From this we know that the onset of cancer is the result of cumulative genetic mutations and epigenetic alterations in tumor cells leading to an unregulated cell cycle, unlimited replicative potential and the possibility for tissue invasion and metastasis. Until recently it was often thought that tumors are more or less undetected or tolerated by the patient's immune system causing the neoplastic cells to divide and spread without resistance. However, it is without any doubt that the tumor environment contains a wide variety of recruited host immune cells. These tumor infiltrating immune cells influence anti-tumor responses in opposing ways and emerges as a critical regulator of tumor growth. Here we provide a summary of the relevant immunological cell types and their complex and dynamic roles within an established tumor microenvironment. For this, we focus on both the systemic compartment as well as the local presence within the tumor microenvironment of late-stage non-small cell lung cancer (NSCLC), admitting that this multifaceted cellular composition will be different from earlier stages of the disease, between NSCLC patients. Understanding the paradoxical role that the immune system plays in cancer and increasing options for their modulation may alter the odds in favor of a more effective anti-tumor immune response. We predict that the future standard of care of lung cancer will involve patient-tailor-made combination therapies that associate (traditional) chemotherapeutic drugs and biologicals with immune modulating agents and in this way complement the therapeutic armamentarium for this disease.
\end{abstract}

Keywords: Lung cancer, Tumor microenvironment, Immune system, Personalized medicine, Cancer immunology

\section{Review}

\section{Current NSCLC treatment}

Treatment of lung cancer is currently based on the patient's clinical signs and symptoms, tumor stage and subtype, medical and family history, and data from imaging and laboratory evaluation. Most conventional cancer therapies, such as radiotherapy and chemotherapy are restricted by adverse effects on normal tissue. Currently NSCLC therapy is moving towards personalized medicine where the genetic profile of each patient's tumor is identified and specific therapies that inhibit the

\footnotetext{
* Correspondence: j.hegmans@erasmusmc.nl

'Department of Pulmonary Medicine, Erasmus Medical Center, Postbox 2040, 3000 CA, Rotterdam, The Netherlands

Full list of author information is available at the end of the article
}

key targets of the oncogenic activation are targeted. In approximately $60 \%$ of all NSCLC cases, specific mutations can be identified, of which $\pm 20 \%$ can be targeted with specific drugs at this moment (e.g. erlotinib, gefitinib, crizotinib). However, most patients receiving conventional cancer treatments or targeted drugs will experience a relapse of tumor growth at a certain time. This sobering outcome demonstrates the necessity of innovative approaches in NSCLC treatment.

Recently, experimental findings and clinical observations have led to cancer-related immune inflammation being acknowledged as an additional hallmark of cancer $[1,2]$. There is currently overwhelming evidence that several immunological cell types of the host influence cancer incidence, cancer growth, response to therapy

\section{Biomed Central}


and thereby the prognosis of the disease. However, the immune system plays a paradoxical role by either preventing cancer growth or in sculpting tumor escape and stimulates its development. A better understanding of the interaction between cancer cells and host immune cells within the tumor environment is of importance for further progress in cancer treatment. This is an extremely difficult task because of the complicated cancerhost immune interactions. The field that studies these interactions, termed cancer immunology, is rapidly progressing. It provides insights into the contribution of the immune system in processes such as tumor invasiveness, metastasis, and angiogenesis and may predict the response to treatment. Most importantly, it also provides opportunities for improved anti-cancer therapies. Modulation of the patient's immune system combined with anti-tumor treatments offers the prospect of tailoring treatments much more precisely and better efficacy for patients with advanced lung cancer.

\section{Immune cells involved in tumorogenesis}

The individual immune related tumor infiltrating cell types are discussed below (Figure 1).

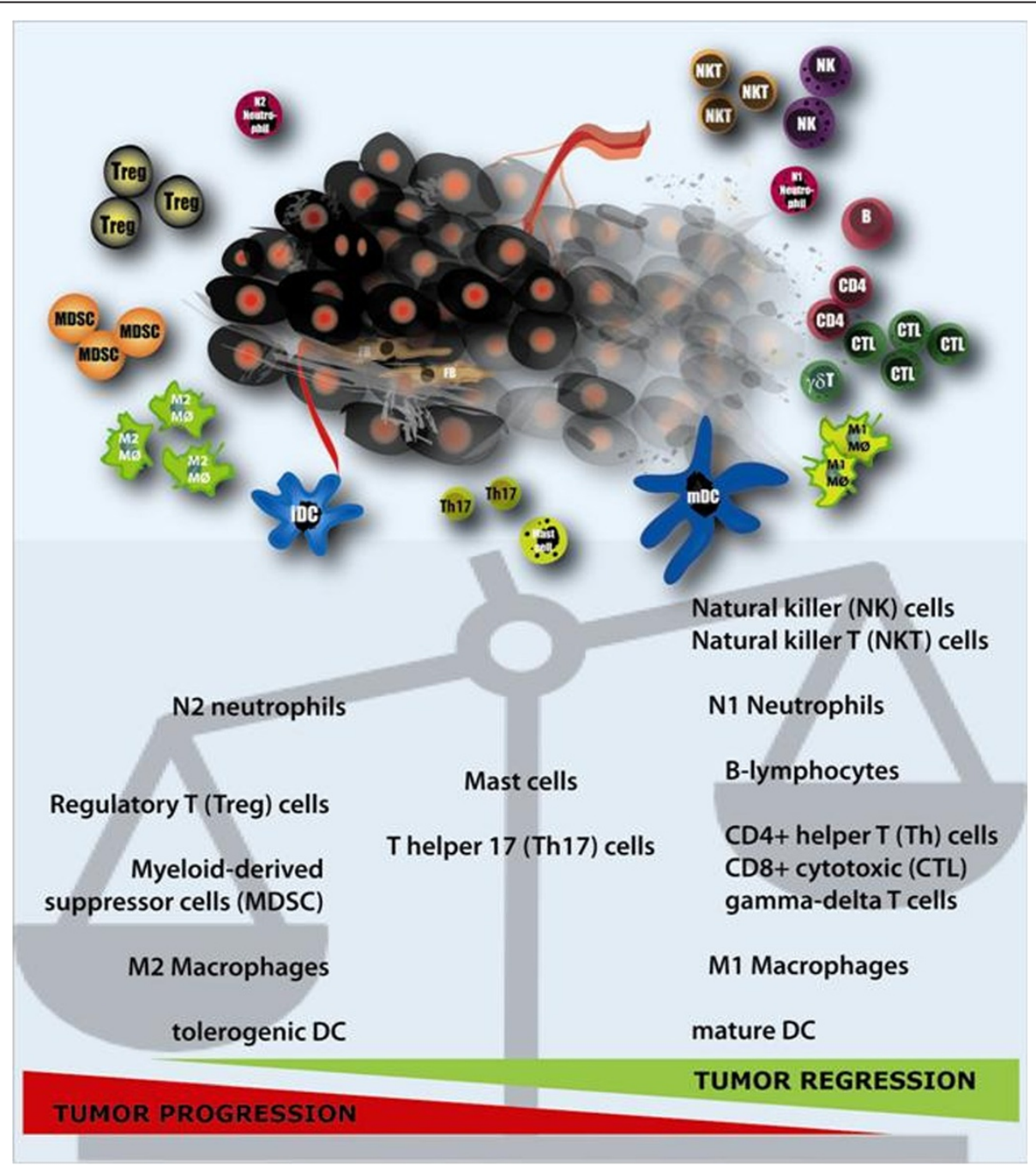

Figure 1 The tumor microenvironment is a heterogeneous and complex system of tumor cells (black) and 'normal' stromal cells, including endothelial cells and their precursors, pericytes, smooth-muscle cells, and fibroblasts of various phenotypes, located within the connective tissue or extra-cellular matrix (e.g. collagen). Leukocyte infiltration is an important characteristic of cancer and the main components of these infiltrates include natural killer (T) cells, neutrophils, B- and T-lymphocyte subsets, myeloid derived suppressor cells, macrophages and dendritic cells [3-7]. Based on their functions, these cells can be divided into cells with a potentially positive impact on the antitumor response (right) and cells with a detrimental effect (left). From mast cells and T helper 17 cells it is yet ambiguous what kind of effect these cells have within the micro-environment. The net effect of the interactions between these various cell types and their secreted products within the environment of an established tumor participates in determining anti-tumor immunity, angiogenesis, metastasis, overall cancer cell survival and proliferation. 


\section{Natural killer (T) cells}

Natural killer (NK) cells (expressing the surface markers CD16 and CD56, but not CD3) are lymphocytes that play an important role in the rejection of tumors without previous sensitization and without restriction by the major histocompatibility complex (MHC) [8,9]. NK cells eradicate tumors through multiple killing pathways, including direct tumor cell killing. They also secrete cytokines and chemokines like Interleukin (IL) IL-10, Tumor Necrosis Factor (TNF)- $\alpha$, and the principal NK-derived cytokine Interferon (IFN)- $\gamma$, which can coordinate the innate and adaptive immune responses to tumor cells and may lead to apoptosis of the attacked cells.

A large cohort study showed that an increase in NK cells in tumor tissue is a strong independent prognostic factor for the survival of lung cancer patients [10]. This is confirmed in mouse models, showing that stimulation of NK cell function protected against NSCLC metastasis $[11,12]$, while depletion enhanced lung cancer metastasis [13]. However, it was recently shown that although the frequencies of NK cells in blood do not differ from healthy controls, stimulated blood NK cells from NSCLC patients with advanced disease had a reduced granzyme $\mathrm{B}$ and perforin A expression, lower production of IFN- $\gamma$, and decreased cytotoxic function indicating that these cells are functionally impaired in comparison with healthy controls $[14,15]$. Adoptive transfer of allogeneic, in vitro activated and expanded NK cells from haploidentical donors was proven potentially clinically effective in NSCLC [16].

Natural killer $\mathrm{T}(\mathrm{NKT})$ cells $\left(\mathrm{CD} 16^{+}, \mathrm{CD}^{+} 6^{+}, \mathrm{CD}^{+}\right)$ are a subset of NK cells that have been found in the peripheral blood, tumor tissue and pleural effusions of lung cancer patients in decreased numbers and with reduced functions $[17,18]$. It has been shown that NKT cells in cancer patients produce a decreased amount of IFN- $\gamma$ and are therefore less effective than NKT cells in healthy controls $[19,20]$. They are currently exploited for cancer treatment by harnessing these cells with CD1d agonist ligands $[21,22]$, or by adoptive transfer of NKT cells activated in vitro [23].

\section{Mast cells}

Accumulation of mast cells is common in angiogenesisdependent conditions, like cancer, as mast cells are a major provider of proangiogenic molecules vascular endothelial growth factor (VEGF), IL-8, transforming growth factor (TGF)- $\beta$ [24]. The density of mast cells in NSCLC tumors is correlated with microvessel density [25] and mast cells / histamine has a direct growth promoting effect on NSCLC cell lines in vitro [26]. However, the role of mast cells in the prognosis in NSCLC remains controversial [25,27-29]. Tumor-infiltrating mast cells can directly influence proliferation and invasion of tumors, by histamine, IL- 8 and VEGF while the production of TNF- $\alpha$ and heparin can suppress tumor growth $[26,30]$. It has been shown that in NSCLC mast cell counts were noted to increase as tumor stage increased while another study did not show this correlation $[24,29]$. Mast cells also play a central role in the control of innate and adaptive immunity by interacting with $\mathrm{B}$ and $\mathrm{T}$ cells (in particular Treg) and dendritic cells. The controversy of mast cells in cancer seems to be related to the type, microenvironment and stage of cancer and their role may depend on the tumor environment $[29,31,32]$. Therapeutic intervention by targeting mast cells, although technically possible [33], is too early without more knowledge on the paradoxical role of these cells in individual cases.

\section{Neutrophils}

Neutrophils play a major role in cancer biology. They make up a significant portion of the infiltrating immune cells in the tumor and the absolute neutrophils count and the neutrophils to lymphocyte ratio in blood are independent prognostic factors for survival of NSCLC [34-36]. Neutrophils are attracted to the tumor under the influence of specific chemokines, cytokines and cell adhesion molecules. Tumor-associated neutrophils (TAN) have polarized functions and can be divided into the N1 and N2 phenotype in a context-dependent manner $[37,38]$. The $\mathrm{N} 1$ phenotype inhibits tumor growth by potentiating $\mathrm{T}$ cell responses while the $\mathrm{N} 2$ phenotype promotes tumor growth [3]. The antitumor activities of $\mathrm{N} 1$ neutrophils include expression of immune activating cytokines (TNF- $\alpha$, IL-12, GM-CSF, and VEGF), T cell attracting chemokines (CCL3, CXCL9, CXCL10), lower expression of arginase, and a better capacity of killing tumor cells in vitro. N2 neutrophils support tumor growth by producing angiogenic factors and matrixdegrading enzymes, support the acquisition of a metastatic phenotype, and suppress the anti-tumor immune response by inducible nitric oxide synthase and arginase expression. Neutrophils also influence adaptive immunity by interacting with T cells [39], B-cells [40], and DC [41]. In resectable NSCLC patients, intratumoral neutrophils were elevated in $50 \%$ of the patients and this was associated with a high cumulative incidence of relapse [42]. Recently, Fridlender et al. showed that TGF- $\beta$ acquired the polarized N2 tumor promoting phenotype of neutrophils in a murine lung cancer model, and blocking of TGF- $\beta$ shifted towards N1 tumor rejecting neutrophils with acquisition of anti-tumor activity in vitro and in vivo [43]. Blockade of TGF- $\beta$ in humans might be a potential utility to prevent polarization towards the protumorigenic N2 phenotype and thereby may result in retarding tumor growth. 


\section{B lymphocytes}

B-cells may affect the prognosis of patients with lung cancer, as patients with stage I NSCLC contain more intratumoral germinal centers with B-lymphocytes than patients with stages II to IV [44]. These tertiary (T-BALT) structures provide some evidence of an adaptive immune response that could limit tumor progression in some patients. For instance, the production of antibodies by Bcells can activate tumor cell killing by NK cells and other inflammatory cells [45]. Auto-antibodies against tumor antigens are commonly found in patients with lung cancer [46-48] and can inhibit micrometastasis [49]. Recently, it has been shown in mice that antibodies produced by $B$ cells interact with and activate Fcy receptors on macrophages and in this way orchestrate antitumor activity [50] or tumor-associated macrophages (TAM)-mediated enhancement of carcinogenesis [51]. Thus, the role of B cells seems depending on the context.

\section{CD4+ and CD8+ lymphocytes}

CD4+ cells and CD8+ cells represent the strong effectors of the adaptive immune response against cancer [52]. There is controversy on the impact of $\mathrm{T}$ cells and their localization on the prognosis of lung cancer [53-59]. This may be caused by the presence of a special subset of $\mathrm{T}$ cells, the regulatory $\mathrm{T}$ cells, and myeloid-derived suppressor cells which are discussed below. Also tumor-derived factors can exhaust $\mathrm{T}$ lymphocytes or induce their apoptosis [60]. Recently it has been shown that cytotoxic $\mathrm{T}$ lymphocytes (CTL) within the tumor (the tumorinfiltrating lymphocytes [TIL]) are of beneficial prognostic influence in resected NSCLC patients in both adenocarcinoma [61] and squamous cell carcinoma [62]. Tumorspecific CD8+ effector T-cells are normally present at a low frequency in cancer patients, but can be expanded up to $50 \%$ of the total circulating CD8+ T-cells by dendritic cell vaccination or adoptive T-cell transfer therapy [6365]. To enhance existing anti-tumor responses, recombinant CD40 ligand or CD40 activating antibodies are investigated as substitute for CD4+ T cell help [66]. Blocking T cell inhibitory molecules such as cytotoxic $\mathrm{T}$ lymphocyte antigen-4 (CTLA-4), lymphocyte activation gene-3 (LAG-3), $\mathrm{T}$ cell immunoglobulin mucin-3 (TIM-3), and programmed death-1 (PD-1) are currently investigated in NSCLC to improve T cell homing and effector functions $[67,68]$. Successes of these experimental therapies in small subsets of patients demonstrate that CTL can be directed against the tumor but mechanisms to induce CTL or overcome the inactivation of $\mathrm{T}$ cell function seems necessary to enable more patients from these treatments.

\section{Regulatory $T$ cells}

Regulatory T cells (Treg), characterized by $\mathrm{CD} 4^{+}, \mathrm{CD} 25^{+}$, Foxp $3^{+}$, and $\mathrm{CD}^{2} 7^{-}$, are $\mathrm{T}$ lymphocytes that are generated in the thymus (natural Treg) or induced in the periphery (induced Treg) when triggered by suboptimal antigen stimulation and stimulation with TGF$\beta$ and IL-10 [69]. Treg are further characterized by the expression of glucocorticoid-induced TNF-receptorrelated-protein (GITR), lymphocyte activation gene-3 (LAG-3), and cytotoxic T-lymphocyte-associated antigen 4 (CTLA4).

In cancer patients, Treg confer growth and metastatic advantages by inhibiting anti-tumor immunity. They have this pro-tumoral effect by promoting tolerance via direct suppressive functions on activated T-cells or via the secretion of immunosuppressive cytokines such as IL-10 and TGF- $\beta$ [70,71]. Treg are present in tumor tissue $[72,73]$ and increased in peripheral blood of NSCLC patients compared to healthy controls $[74,75]$. This increase in Treg was found to promote tumor growth and was correlated with lymph node metastasis $[56,73,76,77]$ and poor prognosis [73,78]. Many factors can increase Treg in NSCLC tumors, among them are thymic stromal lymphopoietin (TSLP) [79] and intratumoral cyclooxygenase-2 (COX-2) expression [80]. Treg are considered the most powerful inhibitors of antitumor immunity [81]. As a result, there is substantial interest for overcoming this barrier to enhance the efficacy of cancer immunotherapy. Strategies include I). Treg depletion by chemical or radiation lymphoablation or using monoclonal antibodies or ligand-directed toxins (daclizumab, basiliximab, denileukin diftitox [Ontak ${ }^{\mathrm{TM}}$, RFT5-SMPT-dgA, and LMB-2) or with metronomic cyclophosphamide. II). Suppression of their function (ipilimumab, tremelimumad [anti-CTLA4], DTA-1 [antiGITR], denosumab [anti-RankL], modulation of Toll-like receptor, OX40 stimulation or inhibiting ATP hydrolysis using ectonucleotidase inhibitors). III). Inhibition of tumoral homing by blocking the selective recruitment and retention of Treg at tumor sites, e.g. CCL22, CXCR4, CD103, and CCR2. IV). Exploitation of T-cell plasticity by modulating IL-6, TGF- $\beta$, and PGE2 expression, e.g. the COX-2 inhibitor celecoxib [82]. Till now, a strategy that specifically target only Treg and no effector $\mathrm{T}$ cells is lacking and procedures that depletes or modulates all Treg should be avoided to minimize the risk of autoimmune manifestations. However, studies modulating Treg in patients are providing some early encouraging results supporting the concept that Treg inhibitory strategies have clinical potential, particularly in those therapies that simultaneously stimulate antitumor immune effector cells.

\section{Gamma delta $T$ cells}

Human $\gamma \delta$-T cells constitute $2-10 \%$ of $\mathrm{T}$ cells in blood and exhibit natural cytolytic activity in an MHCunrestricted manner for microbial pathogens and tumor 
cells. A special TCR on $\gamma \delta$-T cells recognizes small nonpeptide antigens with a phosphate residue and isopentenylpyrophosphate (IPP) that accumulate in tumor cells [83]. Because $\gamma \delta$-T cells recognize target cells in a unrestricted manner, they may exert antitumor effects even on tumor cells with reduced or absent expression of HLA and/or tumor antigens or by provision of an early source of IFN- $\gamma[83,84]$. Phase I clinical trials of in vivo activation of $\gamma \delta$-T cells with zoledronic acid plus IL-2 or adoptive transfer of in vitro expanded $\gamma \delta$-T cells are being conducted at present for lung cancer [85-87].

\section{Th17 cells}

Th17 cells are a subpopulation of $\mathrm{CD}^{+}{ }^{+} \mathrm{T}$ helper cells that are characterized by the production of interleukin17 (IL-17, also known as IL-17A). IL17 plays an important role in the host defenses against bacterial and fungal infections by the activation, recruitment, and migration of neutrophils $[88,89]$. In vitro experiments have shown that IL-1 $\beta$, IL-6, and IL23 promote Th17 generation and differentiation from naïve $\mathrm{CD} 4^{+} \mathrm{T}$ cells [90]. Among the other cytokines secreted by Th17 cells are IL-17F, IL-21, IL-22, and TNF- $\alpha$. The role of Th17 cells in cancer is poorly understood. Th17 cells accumulate in malignant pleural effusion from patients with lung cancer [90]. Also higher levels of IL-17A were detected in serum and in tumor lesions of lung adenocarcinoma patients, indicating a potential role of these cells in cancer [91]. It has been shown that Th17 cells encouraged tumor growth by inducing tumor vascularization or enhancing inflammation, but other studies revealed also opposite roles for Th17 cells. Recent data indicate that IL-17 may play a role in the metastasis of lung cancer by promoting lymphangiogenesis and is therefore an independent prognostic factor in both overall and disease-free survival in NSCLC [92]. However, there is a distinct role for Th17 and Th17-stimulated cytotoxic T-cells in the induction of preventive and therapeutic antitumor immunity in mice by the promoted recruitment of several inflammatory leukocytes, like $\mathrm{DC}, \mathrm{CD}^{+}$and $\mathrm{CD}^{+}$cells [93]. So, it is controversial whether Th17 cells in cancer are beneficial or antagonistic; this may be dependent on the tumor immunogenicity, the stage of disease, and the impact of inflammation and angiogenesis on tumor pathogenesis [94].

\section{Myeloid-derived suppressor cells}

Myeloid-derived suppressor cells (MDSC) are a heterogeneous population of immature myeloid cells and myeloid progenitor cells. MDSC inhibit $\mathrm{T}$ cells activation $[95,96]$ in a nonspecific or antigen-specific manner, alter the peptide presenting ability of MHC class I molecules on tumor cells [97], influence B-cells [98], block NK cell cytotoxicity [99-101], inhibit dendritic cell differentiation
[102], and expand Treg [103,104] signifying their crucial contribution in constituting a tumor suppressive environment. Furthermore, there is compelling evidence that MDSC, by secreting MMP9 and TGF- $\beta 1$, are also involved in angiogenesis, vasculogenesis, and metastatic spread [105].

MDSC suppress the immune system by the production of reactive oxygen species (ROS), nitric oxide (NO), peroxynitrite and secretion of the cytokines IL-10 and TGF- $\beta$ [106]. Upregulated arginase-I activity by MDSC depletes the essential amino acid L-arginine, contributing to the induction of $\mathrm{T}$ cell tolerance by the downregulation of the $\mathrm{CD} 3 \zeta$ chain expression of the $\mathrm{T}$ cell receptor [107-110]. However, the mechanisms that are used to suppress the immune responses are highly dependent on the context of the microenvironment [111].

An increased subpopulation of MDSC in the peripheral blood of NSCLC patients was detected that decreased in those patients that responded to chemotherapy and patient undergoing surgery [112]. Because MDSC play an important role in mediating immunosuppression, they represent a significant hurdle to successful immune therapy in NSCLC. Therefore, targeting MDSC in vivo with drugs like 5-fluorouracil (5FU), gemcitabine or VEGF / c-kit blockers (e.g. sunitinib, imatinib, dasatinib) to elicit more potent anticancer effects is an exciting development [113-115]. Treatment of mice with all-trans retinoic acid (ATRA), along with NKT help, convert the poorly immunogenic MDSC into fully efficient APC and in this way reinforced anti-tumor immune responses [116]. Other MDSC suppressing or differentiation-inducing agents recently reported are 5aza-2/-deoxycytidine, curcumin, IL-10, anti-IL4R aptamer, and vitamin D3 [117-120]. Agents that decrease arginase activity, ROS and/or iNOS expression by MDSC include Nor-NOHA, 1-NMMA, cyclooxygenase 2 inhibitors (celecoxib [121]), phosphodiesterase 5 inhibitors (sildenafil, tadalafil [122]) or reactive oxygen species inhibitors (nitroaspirin [123]). These agents promise to be a fruitful avenue of investigation in the coming years to overcome immune suppression associated by MDSC in advanced tumors [113,114].

\section{Tumor-associated macrophages}

Macrophages are part of the innate immune system and play important roles in the first line of defense against foreign pathogens. They can be divided into M1 macrophages (classical activation) and M2 macrophages (alternative activation). M1 macrophages attract and activate cells of the adaptive immune system and have antitumor and tissue destructive activity, while the M2 phenotype has been linked to tumor-promoting activities by subversion of adaptive immunity, promoting tumor 
angiogenesis and supporting cancer cell survival, proliferation, invasion and tumor dissemination. Macrophages in tumors are usually referred to as tumor-associated macrophages (TAM) and their presence can be substantial (10-65\% of the tumor stroma). In the beginning, the TAM mainly consist of M1-like macrophages however, when the tumor starts to invade and vascularize, there is a skewing towards the M2 phenotype [124,125]. This takes place especially at those regions in the tumor that are hypoxic [126].

It has been reported by several groups that there is an association between the number of tumor islet macrophages and NSCLC survival [58,127-132]. Moreover, when looking at the different phenotypes of TAM (M1 and M2), it is shown that high numbers of M1 macrophages infiltrating the tumor are correlated with improved survival $[130,133]$. On the other hand, the presence of M2-like macrophages is associated with poor clinical outcome [130,133].

Several strategies are currently investigated that influence M2 macrophages at multiple levels. For example, blockade of factors and cytokines secreted by tumor or immune cells to limit the induction of M2 macrophages are investigated [134-136], however this results in loss of typical M2 markers but not their function [137]. It has been shown that inhibiting I $\mathrm{K} B$ kinase (IKK) reprograms the M2 phenotype to the M1 subset [138,139]. Also CD40 therapy seems to skew tumor-infiltrating macrophages towards the M1 phenotype [140]. Influencing the attraction, the polarization or the activation of M2 macrophages may improve survival when combined with standard or other immunotherapeutic regimens.

\section{Dendritic cells}

Dendritic cells (DC) are widely acknowledged as the central surveillance cell type and play an important role in the activation of lymphocyte subsets to control or eliminate human tumors. Upon encountering tumor cells or tumor-associated antigens, DC engulf this material and begin migrating via lymphatic vessels to regional lymphoid organs. The density immature DC (Langerhans cell and interstitial DC) and mature DC, present in the tumor microenvironment is highly predictive of disease-specific survival in early-stage NSCLC patients [141] and the presence of DC in resected NSCLC material is a good prognostic factor [10,142]. Interaction between the DC and tumor cells results in the release of antitumour cytokines [143,144]. This suggests that $\mathrm{DC}$ within the tumor microenvironment of early-stage NSCLC are capable in initiating adaptive immune responses in situ [145-147].

In the peripheral blood and regional lymph nodes of lung cancer patients, the number and function of mature DC is dramatically reduced $[148,149]$, partly due to abnormal differentiation of myeloid cells (e.g. MDSC) [150]. Tumor cells, stromal cells like fibroblasts, and tumor-infiltrating immune cells and/or their secreted products, like VEGF, M-CSF, IL-6, IL-10, and TGF- $\beta$ are also responsible for systemic and local DC defects [151154]. Affected DC are impaired in their ability to phagocytose antigen and to stimulate $\mathrm{T}$ cells, leading to a defective induction of anti-tumor responses.

NSCLC-derived DC produce high amounts of the immunosuppressive cytokines IL-10 and TGF- $\beta$ [155]. It has been shown that the $\mathrm{T}$ cell co-inhibitory molecule B7-H3 and programmed death receptor-ligand-1 (PDL1) are upregulated on tumor residing DC and these molecules conveys mainly suppressive signals by inhibiting cytokine production and $\mathrm{T}$ cell proliferation $[156,157]$.

Tumor-induced modulation is one of the main factors responsible for tumor immune escape and correction of DC function might be a requirement to develop more effective immunotherapeutic strategies against cancer. This might include targeting of those factors with neutralizing antibodies (e.g. anti-VEGF, anti-IL-6) to revert some of the inhibitory effects on DC. Another interesting finding is that culturing monocytes from cancer patients ex vivo, to circumvent the suppressive activity of the tumor milieu, generates DC with a capacity to stimulate allogeneic T cells [158,159]. [160] This finding is important for active DC-based immunotherapeutic approaches, where DC are generated ex vivo from monocytes and after arming with tumor-associated antigens, reinjected into the patient with the intension to restore proper presentation of tumor associated antigens (TAA) and T cell activation [161-163]. This concept is currently tested for NSCLC in therapeutic reality with encouraging results on the immune response, safety and tolerability, despite the small sample sizes of the trials [161-163].

\section{Immunogenic cell death biomarkers}

Lung cancer is a complex disease with limited treatment options, mainly caused by the close relationship between neoplastic cells and healthy cells. To develop a more effective treatment for lung cancer, we have to focus on the complex interactions that tumor cells have with the local stromal compartment and the involved immune cells, and all of their secreted factors. There is growing evidence that the efficacy of many traditional therapeutic treatments depends on their ability to induce proper immunogenic tumor cell death. This specific release of signals upon tumor cell death may lead to immune activation, and in particular anti-tumor immunity, that contribute to the therapeutic outcome for patients [164,165].

There are different candidate immune biomarkers that can predict the efficacy of specific NSCLC anticancer 
therapies [166,167]. In NSCLC, nucleosomes have already been proven useful for the early estimation of response to chemotherapy [168-170]. Presence of mature dendritic cells and CD4+ or CD8+ lymphocytes in NSCLC tumors are independent prognostic factors for overall survival, as described above [55,59,171,172]. In addition, other potentially pivotal markers for lung cancer are p53-specific autoantibodies and pyridoxal kinase (PDXK), the enzyme that generates the bioactive form of vitamin B6 [173]. Also a group of immunogenic cell death biomarkers called damage-associated molecular pattern (DAMP) molecules, can serve as prognostic markers for response to therapy and prognosis in cancer patients [174]. DAMPs, such as surface-exposed calreticulin (ecto-CRT) and the high-mobility group box 1 protein (HMGB1); are released in the blood circulation by late apoptotic and necrotic cells upon oxidative and endoplasmic reticulum (ER) stress. In peripheral blood, they bind to specific immune cells and trigger protective $\mathrm{T}$ cell responses and promote phagocytosis. One of the main functions of HMGB1 is the binding to specific receptors on dendritic cells and other antigen presenting cells, such as receptors for advanced glycation endproducts (RAGE) and toll-like receptors 4 (TLR4). It has been described that the release of DAMP during cell death is essential for the sustained therapy response after chemotherapy and the efficiency of HMGB1 was found to be increased when bacterial lipopolysaccharide (LPS), DNA or nucleosomes were bound to it. Knockdown of HMGB1 was observed to be associated with reduced anticancer immune response and poor therapy outcome. In contrary, overexpression of HMGB1 and its receptor RAGE is pivotal for the metastasizing of the tumor cells as it promotes neoangiogenesis [175]. Markers of immunogenic cell death are becoming a valuable tool in clinical practice for diagnosis and prediction of response to NSCLC therapy and prognosis [167].

Next to DAMP, there are other approaches using RNAand DNA-based immune modifiers to augment cancer therapy efficacy by stimulating the immune system. Bacterial DNA is immunostimulatory and can be replaced using synthetic oligodeoxynucleotides (ODN), for instance CpG oligodeoxynucleotides. CpG ODN are synthetic DNA sequences containing unmethylated cytosineguanine motifs with potent immune modulatory effects via TLR 9 on DC and B cells [176]. They can induce cytokines, activate NK cells, and elicit $\mathrm{T}$ cell responses that lead to strong antitumor effects. It has been shown that CpG ODN downregulates regulatory T cells and TGF- $\beta$ in peripheral blood of NSCLC patients [177].

Overall, analysis of new and conventional therapeutic strategies should not only be focused on the direct cytotoxic effects of tumor cells but also on the initiation of proper immune responses. Simultaneous modulation of the immune system by immune therapeutic approaches can then induce synergistic anticancer efficacy [178]. Overall, the composition of the immunological cells and cell death markers in the host is, next to the mutation analysis and histological features of the tumor, likely to determine the response to specific chemotherapeutic agents and the prognosis of the patients.

\section{Conclusion}

In this review, we have shown that the immune system plays a dual role in cancer development and progression and determines the response to treatment in NSCLC. These complex interactions between diverse immune cell types and tumor cells that can actively favor tumor rejection as well as tumor progression, depends on the tumor type, stage and the types of immune cells that are involved. The data presented here reinforce the importance of full understanding of the intricacy of the cellular interactions within the tumor microenvironment. There is a rapid progress in the field of the cancer immunology and the development of novel cancer immunotherapy approaches. Therefore, tumor immunology will probably be used more commonly in clinical practice in the future, as increasing evidence indicates that the effectiveness of several chemotherapies depends on the active contribution of the different immune effectors. Selecting conventional chemotherapeutic agents that induce proper immunogenic tumor death can synergize with immune response modifiers to revolutionize cancer treatment [179]. Understanding the local and systemic immune mechanisms will lead to new potential therapeutic targets.

We predict that the future standard of care of lung cancer will involve patient tailored combination therapies that associate molecules that target specific genetic mutations or chemotherapeutic drugs with immune modulating agents, driven by the increasing understanding of the immune system in the cancer cell's environment. The future for cancer treatment is bright if we are able to: I). Find a chemotherapeutic drug that induces immunogenic cell death in tumor cells while leaving the normal cells and stimulating immune cells intact. II). Explore ways to efficiently activate the good-natured immune system, for instance, the adoptive transfer of in vitro expanded activated T-cells or NK-cells, and III). Modulate the tumor environment to reduce local and systemic immune suppressive components while limiting potential side-effects for the patient; e.g. by the depletion of Treg by denileukin diftitox or polarizing the M2 macrophage towards the M1 subtype. The treatment has to be tuned to the cellular make-up of each patient individually, based on their own both tumoral and immunological characteristics, rather than by the anatomic location of the tumor in the body or by the tumor 
histology or genetic make-up. This individualized, multitargeted approach will be able to redress the balance towards efficacious antitumor responses that can improve the overall survival for more patients.

\section{Abbreviations}

APC: Antigen presenting cell(s); CTL: Cytotoxic T lymphocyte(s); CTLA4: Cytotoxic T lymphocyte-associated antigen 4; DC: Dendritic cell(s); MDSC: Myeloid-derived suppressor cell(s); NK(T): Natural killer (T) cell(s); TAM: Tumor-associated macrophage(s); TIL: Tumor infiltration lymphocyte(s); Treg: Regulatory T cell(s)

\section{Competing interests}

The authors declare that they have no competing interests.

\section{Authors' contributions}

$\mathrm{MH}$ contributed to literature research, data-analysis, interpretation of findings and drafting of the manuscript. JA contributed to study design, literature research, data-analysis, interpretation of findings and critical editing of the manuscript. RC contributed to literature research, data-analysis, interpretarion of findings and drafting of the manuscript. HG contributed to drafting of the manuscript. $\mathrm{HH}$ contributed to drafting of the manuscript. JH contributed to study design, literature research, data-analysis, interpretation of findings and critical editing of the manuscript. All authors read and approved of the final manuscript.

\section{Author details}

'Department of Pulmonary Medicine, Erasmus Medical Center, Postbox 2040, 3000 CA, Rotterdam, The Netherlands. 'Department of Pulmonary Medicine, Amphia Hospital, Breda, The Netherlands. ${ }^{3}$ Department of Pulmonary Medicine, University Medical Centrum Groningen, Groningen, The Netherlands.

Received: 17 August 2012 Accepted: 15 November 2012 Published: 5 December 2012

\section{References}

1. Cavallo F, De Giovanni C, Nanni P, Forni G, Lollini PL: 2011: the immune hallmarks of cancer. Cancer Immunol Immunother 2011, 60:319-326.

2. Hanahan D, Weinberg RA: Hallmarks of cancer: the next generation. Cell 2011, 144:646-674.

3. Colotta F, Allavena P, Sica A, Garlanda C, Mantovani A: Cancer-related inflammation, the seventh hallmark of cancer: links to genetic instability. Carcinogenesis 2009, 30:1073-1081.

4. Zitvogel L, Kepp O, Aymeric L, Ma Y, Locher C, Delahaye NF, et al: Integration of host-related signatures with cancer cell-derived predictors for the optimal management of anticancer chemotherapy. Cancer Res 2010, 70:9538-9543.

5. Rody A, Holtrich U, Pusztai L, Liedtke C, Gaetje R, Ruckhaeberle E, et al: $\mathrm{T}$-cell metagene predicts a favorable prognosis in estrogen receptornegative and HER2-positive breast cancers. Breast Cancer Res 2009, 11:R15.

6. Schmidt M, Bohm D, von Torne C, Steiner E, Puhl A, Pilch H, et al: The humoral immune system has a key prognostic impact in node-negative breast cancer. Cancer Res 2008, 68:5405-5413.

7. Alexe G, Dalgin GS, Scanfeld D, Tamayo P, Mesirov JP, DeLisi C, et al: High expression of lymphocyte-associated genes in node-negative HER2+ breast cancers correlates with lower recurrence rates. Cancer Res 2007, 67:10669-10676.

8. Becknell B, Caligiuri MA: Natural killer cells in innate immunity and cancer. J Immunother 2008, 31:685-692.

9. Caligiuri MA: Human natural killer cells. Blood 2008, 112:461-469.

10. Al-Shibli K, Al-Saad S, Donnem T, Persson M, Bremnes RM, Busund LT: The prognostic value of intraepithelial and stromal innate immune system cells in non-small cell lung carcinoma. Histopathology 2009, 55:301-312.

11. Yang Q, Goding SR, Hokland ME, Basse PH: Antitumor activity of NK cells. Immunol Res 2006, 36:13-25.

12. Logan RW, Zhang C, Murugan S, O'Connell S, Levitt D, Rosenwasser AM, et al: Chronic shift-lag alters the circadian clock of NK cells and promotes lung cancer growth in rats. J Immunol 2012, 188:2583-2591.
13. Sodeur S, Ullrich S, Gustke H, Zangemeister-Wittke U, Schumacher U: Increased numbers of spontaneous SCLC metastasis in absence of NK cells after subcutaneous inoculation of different SCLC cell lines into pfp/ rag2 double knock out mice. Cancer Lett 2009, 282:146-151.

14. Al Omar SY, Marshall E, Middleton D, Christmas SE: Increased killer immunoglobulin-like receptor expression and functional defects in natural killer cells in lung cancer. Immunology 2011, 133:94-104.

15. Cremer I, Fridman WH, Sautes-Fridman C: Tumor microenvironment in NSCLC suppresses NK cells function. Oncoimmunology 2012, 1:244-246.

16. Iliopoulou EG, Kountourakis P, Karamouzis MV, Doufexis D, Ardavanis A, Baxevanis CN, et al: A phase I trial of adoptive transfer of allogeneic natural killer cells in patients with advanced non-small cell lung cancer. Cancer Immunol Immunother 2010, 59:1781-1789.

17. Shimizu T, Takahashi N, Terakado M, Tsujino I, Hashimoto S: Activation of Valpha24NKT cells in malignant pleural effusion in patients with lung cancer. Oncol Rep 2009, 22:581-586.

18. Rijavec M, Volarevic S, Osolnik K, Kosnik M, Korosec P: Natural killer T cells in pulmonary disorders. Respir Med 2011, 105(Suppl 1):S20-S25.

19. Molling JW, Kolgen W, van der Vliet HJ, Boomsma MF, Kruizenga $H$, Smorenburg CH, et al: Peripheral blood IFN-gamma-secreting Valpha24 +Vbeta11+ NKT cell numbers are decreased in cancer patients independent of tumor type or tumor load. Int J Cancer 2005, 116:87-93.

20. Tahir SM, Cheng O, Shaulov A, Koezuka Y, Bubley GJ, Wilson SB, et al: Loss of IFN-gamma production by invariant NK T cells in advanced cancer. J Immunol 2001, 167:4046-4050.

21. Dhodapkar MV, Richter J: Harnessing natural killer T (NKT) cells in human myeloma: progress and challenges. Clin Immunol 2011, 140:160-166.

22. Wu L, Van Kaer L: Natural killer T cells in health and disease. Front Biosci (Schol Ed) 2011, 3:236-251.

23. Motohashi S, Nakayama T: Natural killer T cell-mediated immunotherapy for malignant diseases. Front Biosci (Schol Ed) 2009, 1:108-116.

24. O'Callaghan DS, O'Donnell D, O'Connell F, O'Byrne K: The role of inflammation in the pathogenesis of non-small cell lung cancer. J Thorac Oncol 2010, 5:2024-2036.

25. Dundar E, Oner U, Peker BC, Metintas M, Isiksoy S, Ak G: The significance and relationship between mast cells and tumour angiogenesis in non-small cell lung carcinoma. J Int Med Res 2008, 36:88-95.

26. Stoyanov E, Uddin M, Mankuta D, Dubinett SM, Levi-Schaffer F: Mast cells and histamine enhance the proliferation of non-small cell lung cancer cells. Lung Cancer 2012, 75:38-44.

27. Al-Shibli K, Al-Saad S, Andersen S, Donnem T, Bremnes RM, Busund LT: The prognostic value of intraepithelial and stromal CD3-, CD117- and CD138positive cells in non-small cell lung carcinoma. APMIS 2010, 118:371-382.

28. Imada A, Shijubo N, Kojima H, Abe S: Mast cells correlate with angiogenesis and poor outcome in stage I lung adenocarcinoma. Eur Respir J 2000, 15:1087-1093.

29. Niczyporuk M, Hermanowicz A, Matuszczak E, Dziadziuszko R, Knas M, Zalewska A, et al: A lack of correlation between mast cells, angiogenesis, and outcome in non-small cell lung cancer. Exp Lung Res 2012, 38:281-285.

30. Khazaie K, Blatner NR, Khan MW, Gounari F, Gounaris E, Dennis K, et al: The significant role of mast cells in cancer. Cancer Metastasis Rev 2011, 30:45-60.

31. Heijmans J, Buller NV, Muncan V, van den Brink GR: Role of mast cells in colorectal cancer development, the jury is still out. Biochim Biophys Acta 2012, 1822:9-13.

32. Nechushtan $\mathrm{H}$ : The complexity of the complicity of mast cells in cancer. Int J Biochem Cell Biol 2010, 42:551-554.

33. Groot Kormelink T, Abudukelimu A, Redegeld FA: Mast cells as target in cancer therapy. Curr Pharm Des 2009, 15:1868-1878.

34. Sarraf KM, Belcher E, Raevsky E, Nicholson AG, Goldstraw P, Lim E: Neutrophil/lymphocyte ratio and its association with survival after complete resection in non-small cell lung cancer. J Thorac Cardiovasc Surg 2009, 137:425-428.

35. Teramukai S, Kitano T, Kishida Y, Kawahara M, Kubota K, Komuta K, et al: Pretreatment neutrophil count as an independent prognostic factor in advanced non-small-cell lung cancer: an analysis of Japan Multinational Trial Organisation LC00-03. Eur J Cancer 2009, 45:1950-1958.

36. Tomita M, Shimizu T, Ayabe T, Yonei A, Onitsuka T: Preoperative neutrophil to lymphocyte ratio as a prognostic predictor after curative resection for non-small cell lung cancer. Anticancer Res 2011, 31:2995-2998. 
37. Mantovani A: The yin-yang of tumor-associated neutrophils. Cancer Cell 2009, 16:173-174.

38. Cortez-Retamozo V, Etzrodt M, Newton A, Rauch PJ, Chudnovskiy A, Berger $C$, et al: Origins of tumor-associated macrophages and neutrophils. ProC Natl Acad Sci U S A 2012, 109:2491-2496.

39. Soehnlein O: An elegant defense: how neutrophils shape the immune response. Trends Immunol 2009, 30:511-512.

40. Puga I, Cols M, Barra CM, He B, Cassis L, Gentile M, et al: B cell-helper neutrophils stimulate the diversification and production of immunoglobulin in the marginal zone of the spleen. Nat Immunol 2012, 13:170-180.

41. Yang D, de la Rosa G, Tewary P, Oppenheim JJ: Alarmins link neutrophils and dendritic cells. Trends Immunol 2009, 30:531-537.

42. Ilie M, Hofman V, Ortholan C, Bonnetaud C, Coelle C, Mouroux J, et al: Predictive clinical outcome of the intratumoral CD66b-positive neutrophil-to-CD8-positive T-cell ratio in patients with resectable nonsmall cell lung cancer. Cancer 2012, 118:1726-1737.

43. Fridlender ZG, Sun J, Kim S, Kapoor V, Cheng G, Ling L, et al: Polarization of tumor-associated neutrophil phenotype by TGF-beta: "N1" versus "N2" TAN. Cancer Cell 2009, 16:183-194.

44. Gottlin EB, Bentley RC, Campa MJ, Pisetsky DS, Herndon JE 2nd, Patz EF Jr: The Association of Intratumoral Germinal Centers with early-stage non-small cell lung cancer. J Thorac Oncol 2011, 6:1687-1690.

45. Pelletier MP, Edwardes MD, Michel RP, Halwani F, Morin JE: Prognostic markers in resectable non-small cell lung cancer: a multivariate analysis. Can J Surg 2001, 44:180-188.

46. Kazarian M, Laird-Offringa IA: Small-cell lung cancer-associated autoantibodies: potential applications to cancer diagnosis, early detection, and therapy. Mol Cancer 2011, 10:33.

47. Mihn DC, Kim TY: Various autoantibodies are found in small-cell lung cancer. Lung Cancer 2009, 64:250

48. Nagashio R, Sato Y, Jiang SX, Ryuge S, Kodera Y, Maeda T, et al: Detection of tumor-specific autoantibodies in sera of patients with lung cancer. Lung Cancer 2008, 62:364-373.

49. Amornsiripanitch N, Hong S, Campa MJ, Frank MM, Gottlin EB, Patz EF Jr: Complement factor $\mathrm{H}$ autoantibodies are associated with early stage NSCLC. Clin Cancer Res 2010, 16:3226-3231.

50. Cittera E, Leidi M, Buracchi C, Pasqualini F, Sozzani S, Vecchi A, et al: The CCL3 family of chemokines and innate immunity cooperate in vivo in the eradication of an established lymphoma xenograft by rituximab. J Immunol 2007, 178:6616-6623.

51. Andreu P, Johansson M, Affara NI, Pucci F, Tan T, Junankar S, et al: FcRgamma activation regulates inflammation-associated squamous carcinogenesis. Cancer Cell 2010, 17:121-134.

52. Andersen MH, Schrama D, Thor Straten P, Becker JC: Cytotoxic T cells. J Invest Dermatol 2006, 126:32-41.

53. Mori M, Ohtani H, Naito Y, Sagawa M, Sato M, Fujimura S, et al: Infiltration of CD8+ T cells in non-small cell lung cancer is associated with dedifferentiation of cancer cells, but not with prognosis. Tohoku J Exp Med 2000, 191:113-118.

54. Trojan A, Urosevic M, Dummer R, Giger R, Weder W, Stahel RA: Immune activation status of CD8+ T cells infiltrating non-small cell lung cancer. Lung Cancer 2004, 44:143-147.

55. Hiraoka K, Miyamoto M, Cho Y, Suzuoki M, Oshikiri T, Nakakubo Y, et al: Concurrent infiltration by CD8+ T cells and CD4+ T cells is a favourable prognostic factor in non-small-cell lung carcinoma. Br J Cancer 2006, 94:275-280

56. Suzuki K, Kachala SS, Kadota K, Shen R, Mo Q, Beer DG, et al: Prognostic Immune Markers in Non-Small Cell Lung Cancer. Clin Cancer Res 2011, 17:5247-5256.

57. Wakabayashi O, Yamazaki K, Oizumi S, Hommura F, Kinoshita I, Ogura S, et al: CD4+ T cells in cancer stroma, not CD8+ T cells in cancer cell nests, are associated with favorable prognosis in human non-small cell lung cancers. Cancer Sci 2003, 94:1003-1009.

58. da Costa Souza P, Parra ER, Atanazio MJ, da Silva OB, Noleto GS, Ab'saber $A M$, et al: Different morphology, stage and treatment affect immune cell infiltration and long-term outcome in patients with non-small-cell lung carcinoma. Histopathology 2012, 61:587-596

59. McCoy MJ, Nowak AK, van der Most RG, Dick IM, Lake RA: Peripheral CD8 (+) T cell proliferation is prognostic for patients with advanced thoracic malignancies. Cancer Immunol Immunother 2012, [Epub ahead of print].
60. Wherry EJ: T cell exhaustion. Nat Immunol 2011, 12:492-499.

61. Kayser G, Schulte-Uentrop L, Sienel W, Werner M, Fisch P, Passlick B, et al: Stromal CD4/CD25 positive T-cells are a strong and independent prognostic factor in non-small cell lung cancer patients, especially with adenocarcinomas. Lung Cancer 2012, 76:445-451.

62. Ruffini E, Asioli S, Filosso PL, Lyberis P, Bruna MC, Macri L, et al: Clinical significance of tumor-infiltrating lymphocytes in lung neoplasms. Ann Thorac Surg 2009, 87:365-371. discussion 71-72.

63. Rosenberg SA, Restifo NP, Yang JC, Morgan RA, Dudley ME: Adoptive cell transfer: a clinical path to effective cancer immunotherapy. Nat Rev Cancer 2008, 8:299-308.

64. Boon T, Coulie PG, Van den Eynde BJ, van der Bruggen P: Human T cell responses against melanoma. Annu Rev Immunol 2006, 24:175-208.

65. Morgan RA, Dudley ME, Wunderlich JR, Hughes MS, Yang JC, Sherry RM, et al: Cancer regression in patients after transfer of genetically engineered lymphocytes. Science 2006, 314:126-129.

66. Fonsatti E, Maio M, Altomonte $M$, Hersey P: Biology and clinical applications of CD40 in cancer treatment. Semin Oncol 2010, 37:517-523.

67. Brahmer JR, Tykodi SS, Chow LQ, Hwu WJ, Topalian SL, Hwu P, et al: Safety and activity of anti-PD-L1 antibody in patients with advanced cancer. N Engl J Med 2012, 366:2455-2465.

68. Lynch TJ, Bondarenko I, Luft A, Serwatowski P, Barlesi F, Chacko R, et al: Ipilimumab in combination with paclitaxel and carboplatin as first-line treatment in stage IIIB/IV non-small-cell lung cancer: results from a randomized, double-blind, multicenter phase II study. J Clin Oncol 2012, 30:2046-2054

69. Ni XY, Sui HX, Liu Y, Ke SZ, Wang YN, Gao FG: TGF-beta of lung cancer microenvironment upregulates $\mathrm{B} 7 \mathrm{H} 1$ and GITRL expression in dendritic cells and is associated with regulatory T cell generation. Oncol Rep 2012, 28:615-621.

70. Thornton AM, Shevach EM: CD4+CD25+ immunoregulatory T cells suppress polyclonal T cell activation in vitro by inhibiting interleukin 2 production. J Exp Med 1998, 188:287-296.

71. Hawrylowicz CM, O'Garra A: Potential role of interleukin-10-secreting regulatory T cells in allergy and asthma. Nat Rev Immunol 2005, 5:271-283

72. Woo EY, Chu CS, Goletz TJ, Schlienger K, Yeh H, Coukos G, et al: Regulatory CD4(+)CD25(+) T cells in tumors from patients with early-stage nonsmall cell lung cancer and late-stage ovarian cancer. Cancer Res 2001, 61:4766-4772.

73. Fu HY, Li C, Yang W, Gai XD, Jia T, Lei YM, et al: FOXP3 and TLR4 protein expression are correlated in non-small cell lung cancer: Implications for tumor progression and escape. Acta Histochem 2012, [Epub ahead of print].

74. Okita R, Saeki T, Takashima S, Yamaguchi Y, Toge T: CD4+CD25+ regulatory $T$ cells in the peripheral blood of patients with breast cancer and nonsmall cell lung cancer. Oncol Rep 2005, 14:1269-1273.

75. Erfani N, Mehrabadi SM, Ghayumi MA, Haghshenas MR, Mojtahedi Z, Ghaderi A, et al: Increase of regulatory T cells in metastatic stage and CTLA-4 over expression in lymphocytes of patients with non-small cell lung cancer (NSCLC). Lung Cancer 2012, 77:306-311.

76. Dimitrakopoulos Fl, Papadaki H, Antonacopoulou AG, Kottorou A, Gotsis AD, Scopa C, et al: Association of FOXP3 expression with non-small cell lung cancer. Anticancer Res 2011, 31:1677-1683.

77. Zaynagetdinov R, Stathopoulos GT, Sherrill TP, Cheng DS, McLoed AG, Ausborn JA, et al: Epithelial nuclear factor-kappaB signaling promotes lung carcinogenesis via recruitment of regulatory T lymphocytes. Oncogene 2011, 31:3164-3176.

78. Tao H, Mimura Y, Aoe K, Kobayashi S, Yamamoto H, Matsuda E, et al: Prognostic potential of FOXP3 expression in non-small cell lung cancer cells combined with tumor-infiltrating regulatory T cells. Lung Cancer 2012, 75:95-101.

79. Li H, Zhao H, Yu J, Su Y, Cao S, An X, et al: Increased prevalence of regulatory $T$ cells in the lung cancer microenvironment: a role of thymic stromal lymphopoietin. Cancer Immunol Immunother 2011, 60:1587-1596.

80. Sharma S, Yang SC, Zhu L, Reckamp K, Gardner B, Baratelli F, et al: Tumor cyclooxygenase-2/prostaglandin E2-dependent promotion of FOXP3 expression and CD4+CD25+ T regulatory cell activities in lung cancer. Cancer Res 2005, 65:5211-5220.

81. Zou W: Regulatory T, cells, tumour immunity and immunotherapy. Nat Rev Immunol 2006, 6:295-307. 
82. Byrne WL, Mills KH, Lederer JA, O'Sullivan GC: Targeting regulatory T cells in cancer. Cancer Res 2011, 71:6915-6920.

83. Gober HJ, Kistowska M, Angman L, Jeno P, Mori L, De Libero G: Human T cell receptor gammadelta cells recognize endogenous mevalonate metabolites in tumor cells. J Exp Med 2003, 197:163-168.

84. Gao Y, Yang W, Pan M, Scully E, Girardi M, Augenlicht LH, et al: Gamma delta $T$ cells provide an early source of interferon gamma in tumor immunity. J Exp Med 2003, 198:433-442.

85. Kobayashi H, Tanaka Y, Yagi J, Minato N, Tanabe K: Phase I/II study of adoptive transfer of gammadelta T cells in combination with zoledronic acid and IL-2 to patients with advanced renal cell carcinoma. Cancer Immunol Immunother 2011, 60:1075-1084.

86. Nakajima J, Murakawa T, Fukami T, Goto S, Kaneko T, Yoshida Y, et al: A phase I study of adoptive immunotherapy for recurrent non-small-cell lung cancer patients with autologous gammadelta T cells. Eur J Cardiothorac Surg 2010, 37:1191-1197.

87. Yoshida Y, Nakajima J, Wada H, Kakimi K: Gammadelta T-cell immunotherapy for lung cancer. Surg Today 2011, 41:606-611.

88. Iwakura $Y$, Ishigame $H$, Saijo S, Nakae S: Functional specialization of interleukin-17 family members. Immunity 2011, 34:149-162.

89. Zou W, Restifo NP: $T(H) 17$ cells in tumour immunity and immunotherapy. Nat Rev Immunol 2010, 10:248-256.

90. Ye ZJ, Zhou Q, Gu YY, Qin SM, Ma WL, Xin JB, et al: Generation and differentiation of IL-17-producing CD4+ T cells in malignant pleural effusion. J Immunol 2010, 185:6348-6354.

91. Li Y, Cao ZY, Sun B, Wang GY, Fu Z, Liu YM, et al: Effects of IL-17A on the occurrence of lung adenocarcinoma. Cancer Biol Ther 2011, 12:610-616.

92. Chen X, Wan J, Liu J, Xie W, Diao X, Xu J, et al: Increased IL-17-producing cells correlate with poor survival and lymphangiogenesis in NSCLC patients. Lung Cancer 2010, 69:348-354.

93. Ankathatti Munegowda M, Deng Y, Mulligan SJ, Xiang J: Th17 and Th17-stimulated CD8(+) T cells play a distinct role in Th17-induced preventive and therapeutic antitumor immunity. Cancer Immunol Immunother 2011, 60:1473-1484.

94. Wilke CM, Kryczek I, Wei S, Zhao E, Wu K, Wang G, et al: Th17 cells in cancer: help or hindrance? Carcinogenesis 2011, 32:643-649.

95. Gallina G, Dolcetti L, Serafini P, De Santo C, Marigo I, Colombo MP, et al: Tumors induce a subset of inflammatory monocytes with immunosuppressive activity on CD8+ T cells. J Clin Invest 2006, 116:2777-2790.

96. Watanabe S, Deguchi K, Zheng R, Tamai H, Wang LX, Cohen PA, et al: Tumor-induced CD11b+Gr-1+ myeloid cells suppress T cell sensitization in tumor-draining lymph nodes. J Immunol 2008, 181:3291-3300.

97. Lu T, Ramakrishnan R, Altiok S, Youn Jl, Cheng P, Celis E, et al: Tumor-infiltrating myeloid cells induce tumor cell resistance to cytotoxic T cells in mice. J Clin Invest 2011, 121:4015-4029.

98. Serafini P, Mgebroff S, Noonan K, Borrello I: Myeloid-derived suppressor cells promote cross-tolerance in B-cell lymphoma by expanding regulatory T cells. Cancer Res 2008, 68:5439-5449.

99. Hoechst B, Voigtlaender T, Ormandy L, Gamrekelashvili J, Zhao F, Wedemeyer $\mathrm{H}$, et al: Myeloid derived suppressor cells inhibit natural killer cells in patients with hepatocellular carcinoma via the NKp30 receptor. Hepatology 2009, 50:799-807.

100. Li H, Han Y, Guo Q, Zhang M, Cao X: Cancer-expanded myeloid-derived suppressor cells induce anergy of NK cells through membrane-bound TGF-beta 1. J Immunol 2009, 182:240-249.

101. Nausch N, Galani IE, Schlecker E, Cerwenka A: Mononuclear myeloidderived "suppressor" cells express RAE-1 and activate natural killer cells. Blood 2008, 112:4080-4089.

102. Cheng P, Corzo CA, Luetteke N, Yu B, Nagaraj S, Bui MM, et al: Inhibition of dendritic cell differentiation and accumulation of myeloid-derived suppressor cells in cancer is regulated by S100A9 protein. J Exp Med 2008, 205:2235-2249.

103. Hoechst B, Ormandy LA, Ballmaier M, Lehner F, Kruger C, Manns MP, et al: A new population of myeloid-derived suppressor cells in hepatocellular carcinoma patients induces CD4(+)CD25(+)Foxp3(+) T cells. Gastroenterology 2008, 135:234-243.

104. Pan PY, Ma G, Weber KJ, Ozao-Choy J, Wang G, Yin B, et al: Immune stimulatory receptor $\mathrm{CD} 40$ is required for T-cell suppression and $\mathrm{T}$ regulatory cell activation mediated by myeloid-derived suppressor cells in cancer. Cancer Res 2010, 70:99-108.
105. Finke J, Ko J, Rini B, Rayman P, Ireland J, Cohen P: MDSC as a mechanism of tumor escape from sunitinib mediated anti-angiogenic therapy. Int Immunopharmacol 2011, 11:856-861.

106. Ostrand-Rosenberg S: Myeloid-derived suppressor cells: more mechanisms for inhibiting antitumor immunity. Cancer Immunol Immunother 2010, 59:1593-1600.

107. Youn Jl, Gabrilovich DI: The biology of myeloid-derived suppressor cells: the blessing and the curse of morphological and functional heterogeneity. Eur J Immunol 2010, 40:2969-2975.

108. Gabrilovich DI, Nagaraj S: Myeloid-derived suppressor cells as regulators of the immune system. Nat Rev Immunol 2009, 9:162-174.

109. Rodriguez PC, Ochoa AC: Arginine regulation by myeloid derived suppressor cells and tolerance in cancer: mechanisms and therapeutic perspectives. Immunol Rev 2008, 222:180-191.

110. Bronte V, Zanovello P: Regulation of immune responses by L-arginine metabolism. Nat Rev Immunol 2005, 5:641-654.

111. Ostrand-Rosenberg S, Sinha P, Beury DW, Clements VK: Cross-talk between myeloid-derived suppressor cells (MDSC), macrophages, and dendritic cells enhances tumor-induced immune suppression. Semin Cancer Biol 2012, 22:275-281.

112. Liu CY, Wang YM, Wang CL, Feng PH, Ko HW, Liu YH, et al: Population alterations of L-arginase- and inducible nitric oxide synthase-expressed CD11b+/CD14/CD15+/CD33+ myeloid-derived suppressor cells and CD8+ T lymphocytes in patients with advanced-stage non-small cell lung cancer. J Cancer Res Clin Oncol 2010, 136:35-45.

113. Apetoh L, Vegran F, Ladoire S, Ghiringhelli F: Restoration of antitumor immunity through selective inhibition of myeloid derived suppressor cells by anticancer therapies. Curr Mol Med 2011, 11:365-372.

114. Kao J, Ko EC, Eisenstein S, Sikora AG, Fu S, Chen SH: Targeting immune suppressing myeloid-derived suppressor cells in oncology. Crit Rev Oncol Hematol 2011, 77:12-19.

115. Ugel S, Delpozzo F, Desantis G, Papalini F, Simonato F, Sonda N, et al: Therapeutic targeting of myeloid-derived suppressor cells. Curr Opin Pharmacol 2009, 9:470-481.

116. Lee JM, Seo JH, Kim YJ, Kim YS, Ko HJ, Kang CY: The restoration of myeloid-derived suppressor cells as functional antigen-presenting cells by NKT cell help and all-trans-retinoic acid treatment. Int J Cancer 2011, 131:741-751.

117. Tu SP, Jin H, Shi JD, Zhu LM, Suo Y, Lu G, et al: Curcumin induces the differentiation of myeloid-derived suppressor cells and inhibits their interaction with cancer cells and related tumor growth. Cancer Prev Res (Phila) 2012, 5:205-215.

118. Roth F, De La Fuente AC, Vella JL, Zoso A, Inverardi L, Serafini P: Aptamermediated blockade of IL4Ralpha triggers apoptosis of MDSCs and limits tumor progression. Cancer Res 2012, 72:1373-1383.

119. Vincent J, Mignot G, Chalmin F, Ladoire S, Bruchard M, Chevriaux A, et al: 5Fluorouracil selectively kills tumor-associated myeloid-derived suppressor cells resulting in enhanced T cell-dependent antitumor immunity. Cancer Res 2010, 70:3052-3061.

120. Poschke I, Kiessling R: On the armament and appearances of human myeloid-derived suppressor cells. Clin Immunol 2012, 144:250-268.

121. Veltman JD, Lambers ME, van Nimwegen M, Hendriks RW, Hoogsteden HC, Aerts JG, et al: COX-2 inhibition improves immunotherapy and is associated with decreased numbers of myeloid-derived suppressor cells in mesothelioma. Celecoxib influences MDSC function. BMC Cancer 2010, 10:464.

122. Serafini P, Meckel K, Kelso M, Noonan K, Califano J, Koch W, et al: Phosphodiesterase- 5 inhibition augments endogenous antitumor immunity by reducing myeloid-derived suppressor cell function. J Exp Med 2006, 203:2691-2702.

123. De Santo C, Serafini P, Marigo I, Dolcetti L, Bolla M, Del Soldato P, et al: Nitroaspirin corrects immune dysfunction in tumor-bearing hosts and promotes tumor eradication by cancer vaccination. Proc Natl Acad Sci U S A 2005, 102:4185-4190.

124. Schmid MC, Varner JA: Myeloid cells in the tumor microenvironment: modulation of tumor angiogenesis and tumor inflammation. $J$ Oncol 2010, 2010:201026

125. Bremnes RM, Al-Shibli K, Donnem T, Sirera R, Al-Saad S, Andersen S, et al: The role of tumor-infiltrating immune cells and chronic inflammation at the tumor site on cancer development, progression, and prognosis: emphasis on non-small cell lung cancer. J Thorac Oncol 2011, 6:824-833. 
126. Lewis C, Murdoch C: Macrophage responses to hypoxia: implications for tumor progression and anti-cancer therapies. Am J Pathol 2005, 167:627-635.

127. Dai F, Liu L, Che G, Yu N, Pu Q, Zhang S, et al: The number and microlocalization of tumor-associated immune cells are associated with patient's survival time in non-small cell lung cancer. BMC Cancer 2010, $10: 220$.

128. Kawai O, Ishii G, Kubota K, Murata Y, Naito Y, Mizuno T, et al: Predominant infiltration of macrophages and CD8(+) T Cells in cancer nests is a significant predictor of survival in stage IV nonsmall cell lung cancer. Cancer 2008, 113:1387-1395.

129. Ma J, Liu L, Che G, Yu N, Dai F, You Z: The M1 form of tumor-associated macrophages in non-small cell lung cancer is positively associated with survival time. BMC Cancer 2010, 10:112.

130. Ohri CM, Shikotra A, Green RH, Waller DA, Bradding P: Macrophages within NSCLC tumour islets are predominantly of a cytotoxic M1 phenotype associated with extended survival. Eur Respir J 2009, 33:118-126.

131. Welsh TJ, Green RH, Richardson D, Waller DA, O'Byrne K, Bradding P: Macrophage and mast-cell invasion of tumor cell islets confers a marked survival advantage in non-small-cell lung cancer. J Clin Oncol 2005, 23:8959-8967.

132. Chung FT, Lee KY, Wang CW, Heh CC, Chan YF, Chen HW, et al: Tumorassociated macrophages correlate with response to epidermal growth factor receptor-tyrosine kinase inhibitors in advanced non-small cell lung cancer. Int J Cancer 2012, 131:E227-E235.

133. Ferlay J, Shin HR, Bray F, Forman D, Mathers C, Parkin DM: Estimates of worldwide burden of cancer in 2008: GLOBOCAN 2008. Int J Cancer 2010, 127:2893-2917.

134. Nakanishi Y, Nakatsuji M, Seno H, Ishizu S, Akitake-Kawano R, Kanda K, et al: COX-2 inhibition alters the phenotype of tumor-associated macrophages from M2 to M1 in ApcMin/+ mouse polyps. Carcinogenesis 2011, 32:1333-1339.

135. Coward J, Kulbe H, Chakravarty P, Leader D, Vassileva V, Leinster DA, et al: Interleukin- 6 as a therapeutic target in human ovarian cancer. Clin Cancer Res 2011, 17:6083-6096.

136. Terlou A, van Seters M, Kleinjan A, Heijmans-Antonissen C, Santegoets LA, Beckmann I, et al: Imiquimod-induced clearance of HPV is associated with normalization of immune cell counts in usual type vulvar intraepithelial neoplasia. Int J Cancer 2010, 127:2831-2840.

137. Heusinkveld M, van der Burg SH: Identification and manipulation of tumor associated macrophages in human cancers. J Transl Med 2011, 9:216.

138. Fong $\mathrm{CH}$, Bebien M, Didierlaurent $A$, Nebauer $R$, Hussell $T$, Broide $D$, et al: An antiinflammatory role for IKKbeta through the inhibition of "classical" macrophage activation. J Exp Med 2008, 205:1269-1276.

139. Hagemann T, Lawrence T, McNeish I, Charles KA, Kulbe H, Thompson RG, et al: "Re-educating" tumor-associated macrophages by targeting NF-kappaB. J Exp Med 2008, 205:1261-1268.

140. Buhtoiarov IN, Sondel PM, Wigginton JM, Buhtoiarova TN, Yanke EM, Mahvi DA, et al: Anti-tumour synergy of cytotoxic chemotherapy and anti-CD40 plus CpG-ODN immunotherapy through repolarization of tumourassociated macrophages. Immunology 2011, 132:226-239.

141. Sautes-Fridman C, Cherfils-Vicini J, Damotte D, Fisson S, Fridman WH, Cremer l, et al: Tumor microenvironment is multifaceted. Cancer Metastasis Rev 2011, 30:13-25.

142. Bremnes RM, Donnem T, Al-Saad S, Al-Shibli K, Andersen S, Sirera R, et al: The role of tumor stroma in cancer progression and prognosis: emphasis on carcinoma-associated fibroblasts and non-small cell lung cancer. J Thorac Oncol 2011, 6:209-217.

143. Becker Y: Dendritic cell activity against primary tumors: an overview. In Vivo 1993, 7:187-191.

144. Mitra R, Singh S, Khar A: Antitumour immune responses. Expert Rev Mol Med 2003, 5:1-19.

145. Kusmartsev S, Gabrilovich Dl: Effect of tumor-derived cytokines and growth factors on differentiation and immune suppressive features of myeloid cells in cancer. Cancer Metastasis Rev 2006, 25:323-331.

146. Pinzon-Charry A, Maxwell T, Lopez JA: Dendritic cell dysfunction in cancer: a mechanism for immunosuppression. Immunol Cell Biol 2005, 83:451-461.

147. Shurin MR, Shurin GV, Lokshin A, Yurkovetsky ZR, Gutkin DW, Chatta G, et al: Intratumoral cytokines/chemokines/growth factors and tumor infiltrating dendritic cells: friends or enemies? Cancer Metastasis Rev 2006, 25:333-356.
148. Almand B, Resser JR, Lindman B, Nadaf S, Clark Jl, Kwon ED, et al: Clinical significance of defective dendritic cell differentiation in cancer. Clin Cancer Res 2000, 6:1755-1766.

149. Bergeron A, El-Hage F, Kambouchner M, Lecossier D, Tazi A: Characterisation of dendritic cell subsets in lung cancer microenvironments. Eur Respir J 2006, 28:1170-1177.

150. Gabrilovich D: Mechanisms and functional significance of tumourinduced dendritic-cell defects. Nat Rev Immunol 2004 4:941-952.

151. Gabrilovich DI, Chen HL, Girgis KR, Cunningham HT, Meny GM, Nadaf S, et al: Production of vascular endothelial growth factor by human tumors inhibits the functional maturation of dendritic cells. Nat Med 1996, 2:1096-1103.

152. Laxmanan S, Robertson SW, Wang E, Lau JS, Briscoe DM, Mukhopadhyay D: Vascular endothelial growth factor impairs the functional ability of dendritic cells through Id pathways. Biochem Biophys Res Commun 2005, 334:193-198.

153. Menetrier-Caux C, Montmain G, Dieu MC, Bain C, Favrot MC, Caux C, et al: Inhibition of the differentiation of dendritic cells from CD34(+) progenitors by tumor cells: role of interleukin- 6 and macrophage colony-stimulating factor. Blood 1998, 92:4778-4791.

154. Steinbrink K, Wolfl M, Jonuleit $H$, Knop J, Enk AH: Induction of tolerance by IL-10-treated dendritic cells. J Immunol 1997, 159:4772-4780.

155. Dumitriu IE, Dunbar DR, Howie SE, Sethi T, Gregory CD: Human dendritic cells produce TGF-beta 1 under the influence of lung carcinoma cells and prime the differentiation of CD4+CD25+Foxp3+ regulatory $T$ cells. $\mathrm{J}$ Immunol 2009, 182:2795-2807.

156. Schneider T, Hoffmann H, Dienemann H, Schnabel PA, Enk AH, Ring S, et al: Non-small cell lung cancer induces an immunosuppressive phenotype of dendritic cells in tumor microenvironment by upregulating $\mathrm{B} 7-\mathrm{H} 3$. J Thorac Oncol 2011, 6:1162-1168.

157. Mu CY, Huang JA, Chen Y, Chen C, Zhang XG: High expression of PD-L1 in lung cancer may contribute to poor prognosis and tumor cells immune escape through suppressing tumor infiltrating dendritic cells maturation. Med Oncol 2011, 28:682-688.

158. Gabrilovich DI, Corak J, Ciernik IF, Kavanaugh D, Carbone DP: Decreased antigen presentation by dendritic cells in patients with breast cancer. Clin Cancer Res 1997, 3:483-490.

159. Ratta M, Fagnoni F, Curti A, Vescovini R, Sansoni P, Oliviero B, et al: Dendritic cells are functionally defective in multiple myeloma: the role of interleukin-6. Blood 2002, 100:230-237.

160. Kvistborg P, Bechmann CM, Pedersen AW, Toh HC, Claesson MH, Zocca MB: Comparison of monocyte-derived dendritic cells from colorectal cancer patients, non-small-cell-lung-cancer patients and healthy donors. Vaccine 2009, 28:542-547.

161. Perroud MW Jr, Honma HN, Barbeiro AS, Gilli SC, Almeida MT, Vassallo J, et al: Mature autologous dendritic cell vaccines in advanced non-small cell lung cancer: a phase I pilot study. J Exp Clin Cancer Res 2011, 30:65.

162. Wang K, Zhou Q, Guo AL, Xu CR, An SJ, Wu YL: An autologous therapeutic dendritic cell vaccine transfected with total lung carcinoma RNA stimulates cytotoxic $T$ lymphocyte responses against non-small cell lung cancer. Immunol Invest 2009, 38:665-680.

163. Zhou Q, Guo AL, Xu CR, An SJ, Wang Z, Yang SQ, et al: A dendritic cellbased tumour vaccine for lung cancer: full-length XAGE-1b proteinpulsed dendritic cells induce specific cytotoxic $T$ lymphocytes in vitro. Clin Exp Immunol 2008, 153:392-400.

164. Galluzzi L, Senovilla L, Zitvogel L, Kroemer G: The secret ally: immunostimulation by anticancer drugs. Nat Rev Drug Discov 2012, $11: 215-233$

165. Hannani D, Sistigu A, Kepp O, Galluzzi L, Kroemer G, Zitvogel L: Prerequisites for the antitumor vaccine-like effect of chemotherapy and radiotherapy. Cancer J 2011, 17:351-358.

166. Zitvogel L, Kepp O, Kroemer G: Immune parameters affecting the efficacy of chemotherapeutic regimens. Nat Rev Clin Oncol 2011, 8:151-160.

167. Holdenrieder S, Nagel D, Stieber P: Estimation of prognosis by circulating biomarkers in patients with non-small cell lung cancer. Cancer Biomark 2010, 6:179-190

168. Alm El-Din MA, Farouk G, Nagy H, Abd Elzaher A, Abo El-Magd GH: Cytokeratin-19 fragments, nucleosomes and neuron-specific enolase as early measures of chemotherapy response in non-small cell lung cancer. Int J Biol Markers 2012, 27:e139-e146. 
169. Holdenrieder S, Stieber P, von Pawel J, Raith H, Nagel D, Feldmann K, et al: Circulating nucleosomes predict the response to chemotherapy in patients with advanced non-small cell lung cancer. Clin Cancer Res 2004 10:5981-5987.

170. Holdenrieder S, von Pawel J, Dankelmann E, Duell T, Faderl B, Markus A, et al: Nucleosomes and CYFRA 21-1 indicate tumor response after one cycle of chemotherapy in recurrent non-small cell lung cancer. Lung Cancer 2009, 63:128-135.

171. Dieu-Nosjean MC, Antoine M, Danel C, Heudes D, Wislez M, Poulot V, et al: Long-term survival for patients with non-small-cell lung cancer with intratumoral lymphoid structures. J Clin Oncol 2008, 26:4410-4417.

172. McCoy MJ, Lake RA, van der Most RG, Dick IM, Nowak AK: Postchemotherapy T-cell recovery is a marker of improved survival in patients with advanced thoracic malignancies. Br J Cancer 2012, 107:1107-1115.

173. Galluzzi L, Vitale I, Senovilla L, Olaussen KA, Pinna G, Eisenberg T, et al: Prognostic impact of vitamin b6 metabolism in lung cancer. Cell Rep 2012, 2:257-269.

174. Stoetzer OJ, Fersching DM, Salat C, Steinkohl O, Gabka CJ, Hamann U, et al: Circulating immunogenic cell death biomarkers HMGB1 and RAGE in breast cancer patients during neoadjuvant chemotherapy. Tumour Biol 2012, [Epub ahead of print].

175. Fahmueller YN, Nagel D, Hoffmann RT, Tatsch K, Jakobs T, Stieber P, et al: Immunogenic cell death biomarkers HMGB1, RAGE and DNAse indicate response to radioembolisation therapy and prognosis in colorectal cancer patients. Int I Cancer 2012, [Epub ahead of print].

176. Murad YM, Clay TM: CpG oligodeoxynucleotides as TLR9 agonists: therapeutic applications in cancer. BioDrugs 2009, 23:361-375.

177. Wang YY, He XY, Cai YY, Wang ZJ, Lu SH: The variation of CD4+CD25+ regulatory $\mathrm{T}$ cells in the periphery blood and tumor microenvironment of non-small cell lung cancer patients and the downregulation effects induced by CpG ODN. Target Oncol 2011, 6:147-154.

178. Ullrich E, Bonmort M, Mignot G, Kroemer G, Zitvogel L: Tumor stress, cell death and the ensuing immune response. Cell Death Differ 2008, 15:21-28.

179. Demaria S: Defining the role of the immune system in cancer treatment: highlights from the Immunochemotherapy Conference. Expert Rev Anticancer Ther 2011, 11:841-843.

doi:10.1186/1471-2407-12-580

Cite this article as: Heuvers et al.: Patient-tailored modulation of the immune system may revolutionize future lung cancer treatment. $B M C$ Cancer 2012 12:580.

\section{Submit your next manuscript to BioMed Central and take full advantage of:}

- Convenient online submission

- Thorough peer review

- No space constraints or color figure charges

- Immediate publication on acceptance

- Inclusion in PubMed, CAS, Scopus and Google Scholar

- Research which is freely available for redistribution 